\title{
Drawing upon a Comparative Case Study of Iraq and Afghanistan Critically Assess the Success and Failures in the Negotiation Process to Get Personnel and/or Humanitarian Aid to Populations in Need
}

\author{
Francesco Bruno \\ Humanitarian and Conflict Response Institute \\ Master of Arts in Peace and Conflict Studies, University of Manchester, UK
}

Received: May 13, 2018 Accepted: June 5, 2018 Online published: June 11, 2018

doi:10.5296/jpag.v8i2.13270～URL: https://doi.org/10.5296/jpag.v8i2.13270

\begin{abstract}
This paper critically assesses and compares the successes and failures of Non-Governmental Organizations(NGOs) in negotiating access to humanitarian spaces in two case studies, namely Afghanistan and Iraq. The case studies have been selected due to the nature of the two wars, namely the link to the "War on Terror" declared by President George W. Bush in 2001. As a consequence, the selected cases highlight highly politicized and insecure environments for the NGOs to work in. In terms of successes, the NGOs became more flexible in their organizational structure while solving cases on a day-to-day basis negotiating access with local as well as international actors. However, the nature of the conflicts completely shuttered any opportunity to uphold the principles of impartiality, neutrality and independence. In terms of failures, the case studies point out one of the main and most recurrent dilemmas for the NGOs, namely the lack of legitimacy and independency. As a consequence, many international NGOs engaged in remote projects using local personnel in insecure and dangerous areas lacking tools for monitoring the progresses and successes.
\end{abstract}

Keywords: humanitarian access, humanitarianism, Iraq, Afghanistan, war on terror, non-governmental organizations

\section{Introduction}

This aim of this paper is to compare and critically assess the successes and failures of Non-Governmental Organizations(NGOs) in the negotiation process to open humanitarian spaces in Iraq and Afghanistan. The choice of the two case studies links directly to the roots of both conflicts, namely 'the War on Terror' started by President George W. Bush in the 
aftermath of the terrorist plot of September 11,2001. The paper focuses on understanding the successes and failures of NGOs in two highly politicized and insecure environments. On the one hand, in terms of successes, the paper will address a very small number of successes based on a day-to-day problem-solving approach to practical issues raised by NGOs in both case studies. In Iraq, the creation of a NGO Coordination Committed Committee in Iraq(NCCI) assumed the role of broker for NGOs in negotiating with US forces, local ministries and other actors that characterized the environment in Iraq, namely private contractors that were, mostly, associated with the US government. Similar situation characterized Afghanistan, where NGOs had to deal with an ambivalent role of humanitarian relief and development, that created profound issues in preserving humanitarian space and uphold their principles of impartiality, neutrality and independence. On the other hand, in terms of failures, the two case studies have pointed out a profound dilemma for humanitarian actors: should they have continued to serve the needs of the population or withdrawn due to ideological constraints? In both countries, NGOs' perceived lack of legitimacy, which continued to undermine their ability to implement project and provide assistance to those in need. Finally, the situation has been based on a continuous state of insecurity resulting in many international actors to relocate their offices and work with a low profile in diminishing their ability to perform risk-assessments and monitor the implementation of the projects.

\section{Analysis}

The first part of this paper defines what 'Humanitarian space' means and why NGOs should, therefore, be advantaged in dealing with the expansion of Humanitarian spaces in which they uphold their principles, and access the population in need. In defining Humanitarian Space, this paper will use the definition of Rony Brauman in which he states 'it is an environment in which humanitarian agencies that abide to the principles of neutrality, impartiality and independence, could operate independently of external political agendas'. ${ }^{1}$ Consequently, humanitarian agencies give great importance to the respect of International Humanitarian Law (IHL), in which the safety of humanitarian workers in conflict-affected environments and their ability to access population in need due to war-conditions is set out. In order to access to these affected-areas, NGOs are also very adaptable players. They are, indeed, able to convince government or some other entity to do something specific; for instance, to persuade an armed non-state actor to provide medical assistance or food aid to an area they occupy. $^{2}$

\section{Afghanistan: The Context}

In terms of contextualization, the War on Terror began with Bush's speech in 2001 after the terror plot of 9/11, has created the premises for the invasions of Iraq and Afghanistan. On the one hand, there is Afghanistan, which is a very special case. It went through multiple periods of instability and regime changes since the Soviets withdrew in 1989. The most important of these has been the rise of the Taliban regime that took control of the government in Kabul in

\footnotetext{
1 Don Hubert and Cynthia Brassard-Boudreau. 'Questioning Humanitarian Spaces' in Acuto, M. (2014). Negotiating relief. London: Hurst p.14

2 Roeder, Larry Winter, Simard, Albert. (2013). Diplomacy and Negotiation for Humanitarian NGOs (1st ed.). New York, NY: Springer p.1
} 
1996. Most significantly, they are a Sunni fundamentalist group that fights for 'installing a version of the Sharia Law'. ${ }^{3}$ In this sense, they slowly became able to challenge the government in Kabul and found support among the Afghan population. Afghani villagers say that 'the Taliban drove out the remaining minority of government sympathizers through intimidation and assassination. Then they won over the majority with promises of security and efficiency. They implemented a harsh version of Sharia law, cutting off the hands of thieves and shooting adulterers. They were brutal, but they were also incorruptible. Justice no longer went to the highest bidder'. They officially gained control of Afghanistan in 1996. Since then, 'a great deal of optimism prevailed in US-Taliban ties, and US played the role of a clandestine partner in the new "Great Game"" with multiple objectives, but most of all, 'placing in Afghanistan a government that could serve and watch dog US interests in South Asia'5 The U-turn took place with 9/11, when the US accused the Taliban of hosting the culprits of the terror plot, namely Al-Qaeda, and, more importantly, 'the Taliban refused to hand over to US, Osama Bin Laden'. 6 Consequently, on the basis of the War on Terror declared by President Bush a few months earlier, the International Security Assistance Force (ISAF) composed of US forces and supported by NATO partners, invaded Afghanistan and overthrew the Taliban government and began the process of reconstruction of the country.

\section{Iraq: The context}

Iraq is a different case than Afghanistan; it had been under the control of Saddam Hussein's regime for almost 30 years. Iraq became more relevant to US foreign policy when the Iraqi army invaded and annexed Kuwait in 1990. The annexation brought the international community to condemn Saddam, freeze Iraqi and Kuwaiti assets and the imposition of a total economic and trade embargo on Iraq and Iraq's only oil export pipelines through Turkey and Saudi Arabia were promptly cut'. In 1991, the UN passed Resolution 678 asking 'for the unconditional withdrawal of Iraqi troops from Kuwait [...] and authorised the use of military force if Iraq failed to comply'. ${ }^{8}$ When Iraq failed to comply Operation Desert Storm was initiated and, within one month, the Iraqi troops were routed and withdrew from Kuwait. After the war, the UN Security Council (UNSC) agreed that "Iraq should be prevented from launching similar aggressions in the future requested to open up all sites for inspection by UN teams searching for evidences of Iraq's suspected programmes of nuclear, chemical and biological weapons development. Once discovered, these would be destroyed". The investigation revealed "that Iraq "was on the verge of developing its own

\footnotetext{
3 Anand Gopal,. (2008). Anand Gopal Who Are the Taliban?. Retrieved from http://anandgopal.com/who-are-the-taliban/ or http://frontierweekly.com/archive/vol-number/vol/vol-41-2008-09/vol-41-29\%20Feb\%201-7\%202009/taliban-4 1-29.pdf p. 2

4 Anand Gopal, "Who Are the Taliban?. p. 2

5 Imtiyaz, Gul Khan,. (2017). Afghanistan: US Policy and Post 9/11 Afghan War Scenario. International Journal of Scientific and Research Publications, 2 (4): 1-8. http://www.ijsrp.org/research_paper_apr2012/ijsrp-apr-2012-37.pdf.. p.2

6 Imtiyaz Gul Khan, "Afghanistan: US Policy And Post 9/11 Afghan War Scenario”, p.2

7 Charles Tripp (2010). A history of Iraq (1st ed.). Cambridge, UK: Cambridge University Press p.244

${ }^{8}$ Charles Tripp, A History Of Iraq p. 244

9 Charles Tripp, A History Of Iraq. p.250
} 
nuclear device". ${ }^{10}$ Since then, the burden of the economic sanctions and the massive destruction brought by Operation Desert storm in 1991 left the country in economic and financial stagnation, bringing high levels of malnutrition, diseases and infant mortality to rise and take a toll on victims. However, Saddam Hussein never fully complied with UNSCOM and even banned the UN teams from Iraq in 1998 as well as continued to make it appear that he possessed weapons of mass destruction. When Iraq failed to comply with the international community, Bush unleashed 'Operation Iraqi Freedom' that decapitated the regime, and created the Coalition Provisional Authority (CPA) which worked as Iraq's transitional government until the elections.

\section{Successes}

The successes of humanitarian diplomacy in Iraq and Afghanistan have been extremely modest. In terms of Iraq, the humanitarian situation should be seen as the consequence of a decade of economic sanctions, when most of the Iraqi population 'remained particularly vulnerable and completely dependent on state-run services: monthly food distribution, access to healthcare and other basic services'. ${ }^{11}$ Turning to Afghanistan, it has been to the recipient of humanitarian action for longer, 'which has been intersected with, political, military, human rights and socio-economic dimensions of the crisis'. ${ }^{12}$ In addition, after the 9/11 terror attack connected the dots and the "al-Qaida network was identified as responsible for the atrocities, alongside its host Taliban regime, Afghanistan became the prime part of the enemy in President Bush's declared 'war on terror"'. ${ }^{13}$ The Afghan war was, therefore, justified upon the idea that the Afghan regime was hosting Al-Qaeda. On the other hand, the US invasion of Iraq was openly seen as a violation of International Law and sovereignty by many governments and people around the globe, but in line with the principle of 'Pre-emption' that allows the use of military force as an aggressive tool. In the case of Iraq, the use of military force was due to 'the naked aggression by Iraq against its neighbours, its efforts to obtain weapons of mass destruction, its record of having used such weapons'. ${ }^{14}$ In other words, there are two distinct contexts; Iraq is a war in which there are allies and enemies, while in Afghanistan, to ask Donini's question, 'Is it a Humanitarian crisis or a post-conflict, peacebuilding and/or statebuilding situation?' ${ }^{15}$ These contexts reflected the way humanitarian actors were perceived on the ground by locals.

Despite very different humanitarian situations, Iraq and Afghanistan have seen similar scenarios in terms of the success of the humanitarian action. In both case studies, humanitarian players found controversial situations on the ground that permitted them to

${ }^{10}$ Charles Tripp, A History Of Iraq. p.251

${ }^{11}$ Claudia, Rodriguez .(2007) 'The Legitimacy of Humanitarian Action in Iraq' in Minear, L., Minear, L., Smith, H., \& Smith, H. (2007). Humanitarian diplomacy. Tokyo: United Nations University Press. , p.110

${ }^{12}$ Antonio ,Donini, Negotiating with the Taliban in Minear, L., Minear, L., Smith, H., \& Smith, H. (2007).

Humanitarian diplomacy. Tokyo: United Nations University Press. . p.154

${ }_{13}$ Paul Rogers, (2004). A war on terror (1st ed.). London: Pluto Press.p. 2

${ }^{14}$ William H,Taft, and Todd F Buchwald. (2004). Preemption, Iraq, and International Law. The American Journal Of International Law, 97(3), 557 - 563. doi: 10.2307/3109840 p. 557-558

${ }^{15}$ Antonio, Donini,.(2007). Local Perceptions of Assistance to Afghanistan. International Peacekeeping, 14(1), 158 172. doi: 10.1080/13533310601114376 p.160 
achieve case-by-case success in accessing communities. In this sense, the NGOs had to adopt a different rhetoric and use different methods to deal with a large number of players in the two contexts. In both cases, the humanitarian actors had to deal with the Coalition forces (ISAF and CPA) and the ministries (Iraqi and Afghan) that were directly managed by the coalitions' advisers, in addition to Ba' athist fugitives and insurgents (in Iraq) or Al-Qaeda and Taliban (in Afghanistan), as well as third-party players such as private contractors. Based on this wide range of actors, both cases have highlighted the need for international humanitarian actors, particularly NGOs, to preserve humanitarian space through the creation of platforms or brokers in order to connect them to the numerous players on the ground. However, in the case of Iraq, international humanitarian actors created the NGO Coordination Committee in Iraq (NCCI) 'in response to growing concerns about preserving humanitarian space and safeguarding the neutrality, impartiality and operational independence of humanitarian activity within the framework of the occupation'. ${ }^{16}$ In the case of Afghanistan, the situation is more complex due to the politicization of humanitarian aid for security purposes; this therefore assumed the role of winning consensus among the Afghan population and was in line with the American foreign policy. ${ }^{17}$ Consequently, NGOs were never able to assume such a unified front due to lack of legitimacy. They therefore worked independently establishing projects following the double-track that characterized their identity in Afghanistan, namely development and humanitarian assistance. On the one hand, they established programs for food security, water purification, and sanitation providing basic services to communities more complacent to the international presence and the newly appointed Afghan government. On the other hand, they also implemented projects more in line with the developmental sphere including programs spanning from capacity building to economic reconstruction and following the government's program named 'the National Solidarity Programme' to empower local villages. ${ }^{18}$ Therefore, in Iraq the NCCI was able to represent a unified front and interact with ministries and coalition forces as well as to seek concrete case-by-case solutions to "NGOs main operational constraints; pursuing a more process-oriented engagement with different platers for wider, sustainable and more principled objectives' ${ }^{19}$ In this case, NCCI was used to negotiate with local and international actors to access siege towns or during ongoing fights between the coalition forces and non-state armed groups. However, these achievements were reached on day-to-day compromises that did not guarantee the long-term establishment of these humanitarian spaces.

\section{Failures}

The failures of humanitarian diplomacy can be seen as a direct consequence of the 'War on Terror'. When President Bush stated that 'Every nation, in every region, now has a decision to make. Either you are with us, or you are with the terrorists' he created the foundations

${ }^{16}$ Claudia, Rodriguez "The Legitimacy of Humanitarian Action in Iraq' p.111

${ }_{17}$ Paul, Fishstein, and Andrew Wilder. (2012). Winning Hearts and Minds? Examining the Relationship between Aid and Security in Afghanistan | Tufts - Feinstein International Center. Retrieved from http://fic.tufts.edu/publication-item/winning-hearts-and-minds-examing-the-relationship-between-aid-and-securi ty-in-afghanistan/ p.8

${ }^{18}$ Lara, Olson,. (2006). "Fighting for humanitarian space: NGOS in Afghanistan. Journal of Military and Strategic Studies 9 (1): 1-28. http://jmss.org/jmss/index.php/jmss/article/viewFile/121/133 .p.7

${ }^{19}$ Claudia Rodriguez, 'The Legitimacy of Humanitarian Action in Iraq' p.112 
upon which this War on Terror should be conducted, which include the use of humanitarian assistance. ${ }^{20}$ There have been multiple issues that have shared experiences in Afghanistan and Iraq and which have consequently undermined the impact of humanitarian access in both countries. In both states, one of the main driving factors should be seen as a "perception gap', namely the significant disconnection between how outsiders and local communities view what is happening in the country - and its implications for actors in the aid community". ${ }^{21}$ In Iraq, "the humanitarian landscape before the war was characterized by the role of the Iraqi government, which was responsible for distributing food and giving healthcare'. ${ }^{22}$ In this context, humanitarian assistance was never given following the principles of impartiality, neutrality and independence, but always in connection with Saddam's regime. In this situation, humanitarianism was understood through Islamic teachings, 'equating specific humanitarian principles with Qur'anic verses about 'good' charity'. ${ }^{23}$ When the coalition overthrew Saddam's regime, "the exercises of neutrality, impartiality, and independence in Iraq came to be understood as an 'anti-Americanism' phenomenon" and therefore Humanitarian agencies became the 'peaceful tool' of a violent enemy. $^{24}$

In Afghanistan, by contrast, humanitarian assistance is well-understood due to the NGOs' long-commitment to the country, but it has not been able to take a proper stance regarding its role in the country, resulting in the spiral of politicization in which 'humanitarian and social development makes aid policies more overtly and directly determined by Western foreign policy goals rather than by humanitarian principles'. ${ }^{25}$ This has led NGOs not only to legitimize 'regime change', and therefore the American-backed regime in Kabul, but also to become directly and indirectly part of a broader agenda of the War on Terror in which NGOs' humanitarian principles could not function. ${ }^{26}$ In this sense, the presence of 'joint teams of international civilian and military personnel operating at the provincial level [i.e. the Provincial Reconstruction Teams (PRTs)] has managed not only in security, but also in reconstruction, support to central governance and limited relief operations'; PRTs have therefore become a decisive tool for the international coalition and military strategists, using

${ }^{20}$ George W. Bush,. (2001). CNN.com - Transcript of President Bush's address - September 21, 2001. Retrieved from http://edition.cnn.com/2001/US/09/20/gen.bush.transcript/

21 Antonio, Donini. Local Perceptions of Assistance to Afghanistan p.158

22 Claudia, Rodriguez, 'The Legitimacy of Humanitarian Action in Iraq' p.111

${ }^{23}$ Greg, Hansen,. 2017. Coming to Terms with the Humanitarian Imperative in Iraq | Tufts - Feinstein International

Center.

Retrieved

from

http://fic.tufts.edu/publication-item/coming-to-terms-with-the-humanitarian-imperative-in-iraq/ p.5

${ }^{24}$ Greg, Hansen, (2017). Taking Sides or Saving Lives: Existential Choices for the Humanitarian Enterprise in Iraq $\quad$ Tufts $\quad-\quad$ Feinstein International Center. Retrieved from http://fic.tufts.edu/publication-item/taking-sides-or-saving-livesexistential-choices-for-the-humanitarian-enterpri se-in-iraq/ pp.30 - 31

25 Shannon, Roisin (2009). Playing with principles in an era of securitized aid. Progress In Development Studies, 9(1), 15-36. doi: 10.1177/146499340800900103. p.17

26 Shannon Roisin,, Playing with principles in an era of securitized aid: negotiating humanitarian space in post-9/11 Afghanistan p.26 
aid as a bargaining chip to attract the favour of the Afghan population. ${ }^{27}$ In this way, NGOs have found themselves losing their legitimacy to access communities in areas in which Taliban-affiliated groups are in control. In this sense, NGOs were therefore 'divided about the extent of which humanitarian aid should address the political causes of suffering' that plays a great role in the Afghan context. ${ }^{28}$ Consequently, humanitarian access has been drastically reduced and only includes ISAF- and government-controlled areas.

A second main issue is the security risks that NGOs had to take. In addressing this issue, there has been a 'credibility gap' between NGOs and their recipients on the ground in both contexts. In both countries, NGOs became targets for bombings and kidnappings. In the case of Iraq, the International Committee of the Red Cross headquarter bombing on $19^{\text {th }}$ of April, 2003, provoked a strong international response and promptly led NGOs to leave Iraq by the end of 2003, while in Afghanistan international personnel were kidnapped, and often killed, by the Taliban. Consequently, in Iraq, NGOs started to work in low-profile mode and far from the field, remaining confined in the secured Green Zones and leaving the task of delivering food to local aid workers, while trying to assess the situation from a distance. In this sense, security risks such as 'hostage-taking and executions of foreigners continued to be a problem and were the main reason for reducing the operational response of many NGOs and the eventual closure of relief programmes in the country'. ${ }^{29}$ Similarly, in Afghanistan, NGOs adopted comparable measures due to attacks conducted by Taliban and related groups toward international personnel. In addition, there was a sense of 'anti-Americanism/anti-Afghan government elements' that brought an increase in attacks against ISAF and Afghan government military personnel, including attacks against NGOs due to the inability of insurgents and locals to distinguish between the identities of the various foreign forces in Afghanistan, including PRTs who often wore civilian clothes and carried out NGO-type activities. ${ }^{30}$ Consequently, this situation caused a decline in the conditions in which NGOs could operate, monitor the developments of their projects and reach communities in need. In this context, they opted to use 'unmarked vehicles, not signposting offices, 24-hour monitoring of staff, local staff carrying no identification, use of public transport for local staff' ${ }^{31}$ In both countries, the adoption of this low-profile approach undermined humanitarian access and the ability to fulfil the basic functions of their missions.

\section{Conclusion}

In conclusion, the role of humanitarian diplomacy has been extremely undermined in the contexts of Iraq and Afghanistan. Consequently, NGOs found themselves to be stuck in a battle between principles and morality; a battle between legitimacy and a new international perspective that enlisted humanitarian aid as part of a broader strategy to win over the Afghan

\footnotetext{
27 Shannon Roisin, , Playing with principles in an era of securitized aid: negotiating humanitarian space in post-9/11 Afghanistan. p.17

${ }_{28}^{28}$ Lara, Olson, Fighting For Humanitarian Space: Ngos In Afghanistan p.10

29 Claudia, Rodriguez, The Legitimacy of Humanitarian Action in Iraq p.113

30 Shannon Roisin, , Playing with principles in an era of securitized aid: negotiating humanitarian space in post-9/11 Afghanistan p.22 - Antonio, Donini, Local Perceptions of Assistance to Afghanistan, p.168

31 Shannon Roisin, Playing with principles in an era of securitized aid: negotiating humanitarian space in post-9/11 Afghanistan p.24
} 
and Iraqi populations. In this context, the role of humanitarian diplomacy became unable to create Humanitarian space to allow NGOs to have an effective role. The issues regarding the perception and credibility gaps have remained important issues upon which NGOs can learn vital lessons and renew their identities. In both contexts, NGOs need to re-establish the integrity of humanitarian principles through a coordinated and independent body that would allow them to distinguish themselves from other actors on the ground, including private contractors and PRTs who play an important role in the CPA and ISAF war schemes. Therefore, NGOs need a new commitment to their recipients, rather than to their donors, in order to allow them to align with the needs of locals. It will require time to re-establish that credibility which has been lost since 2001, but it remains an essential step forward to allow the consolidation of their identities and slowly engage more actors in order to expand humanitarian space. NGOs remain an important tool for engaging non-state actors in diplomatic and political acts that could bring important results to stop the conflicts and promote dialogue among actors.

\section{Acknowledgement}

The research has been inspired by my personal interest in understanding how to improve the relationship between humanitarian world and the role of the military forces. Many thanks to the Humanitarian and Conflict Response Institute at the University of Manchester for developing my interest further.

\section{Reference}

Bush, G. (2001). CNN.com - Transcript of President Bush's address - September 21, 2001. Retrieved from http://edition.cnn.com/2001/US/09/20/gen.bush.transcript/ .

Donini, A. (2007). Local Perceptions of Assistance to Afghanistan. International Peacekeeping, 14(1), 158-172. https://doi.org/10.1080/13533310601114376

Donini, A., Minear, L., \& Smith, H. (2007). Humanitarian diplomacy. Tokyo: United Nations University Press..

Fishstein, P., \& Wilder, A. (2012). Winning Hearts and Minds? Examining the Relationship between Aid and Security in Afghanistan | Tufts - Feinstein International Center. Retrieved from

http://fic.tufts.edu/publication-item/winning-hearts-and-minds-examing-the-relationship-betw een-aid-and-security-in-afghanistan/

Gopal, A. (2008). Anand Gopal Who Are the Taliban?. Retrieved from http://anandgopal.com/who-are-the-taliban/ or http://frontierweekly.com/archive/vol-number/vol/vol-41-2008-09/vol-41-29\%20Feb\%201-7 $\% 202009 /$ taliban-41-29.pdf

Gul, K.I. (2017). Afghanistan: US Policy and Post 9/11 Afghan War Scenario. International Journal of Scientific and Research Publications, 2(4),1-8. http://www.ijsrp.org/research_paper_apr2012/ijsrp-apr-2012-37.pdf. 


\section{Macrothink}

Journal of Public Administration and Governance ISSN 2161-7104 2018, Vol. 8, No. 2

Hansen, G. (2017). Coming to Terms with the Humanitarian Imperative in Iraq | Tufts Feinstein International Center. Retrieved from http://fic.tufts.edu/publication-item/coming-to-terms-with-the-humanitarian-imperative-in-ira q/

Hansen, G. (2017). Taking Sides or Saving Lives: Existential Choices for the Humanitarian Enterprise in Iraq | Tufts - Feinstein International Center. Retrieved from http://fic.tufts.edu/publication-item/taking-sides-or-saving-lives-existential-choices-for-the-h umanitarian-enterprise-in-iraq/

Hubert, D., Brassard, B. C. (2014). 'Questioning Humanitarian Spaces' in Acuto, M. Negotiating relief. London: Hurst.

IV, W., \& Buchwald, T. (2004). Preemption, Iraq, and International Law. The American Journal of International Law, 97(3), 557 - 563. https://doi.org/10.2307/3109840

Olson, L. (2006).Fighting for humanitarian space: NGOS in Afghanistan. Journal of $\begin{array}{lllll}\text { Military and } \quad \text { Strategic } & \text { Studies, } & 9(1), & \text { 1-28. }\end{array}$ http://jmss.org/jmss/index.php/jmss/article/viewFile/121/133.

Rodriguez, C. (2007). The Legitimacy of Humanitarian Action in Iraq' in Minear, L., Minear, L., Smith, H., \& Smith, H. (2007). Humanitarian diplomacy. Tokyo: United Nations University Press.

Roeder, J. L., \& Simard, A. (2013). Diplomacy and Negotiation for Humanitarian NGOs (1st ed.). New York, NY: Springer. https://doi.org/10.1007/978-1-4614-7113-4

Rogers, P. (2004). A war on terror (1st ed.). London: Pluto Press.

Shannon, R. (2009). Playing with principles in an era of securitized aid. Progress In Development Studies, 9(1), 15-36. https://doi.org/10.1177/146499340800900103

Tripp, C. (2010). A history of Iraq (1st ed.). Cambridge, UK: Cambridge University Press.

\section{Suggested readings}

Acuto, M. (2014). Negotiating relief (1st ed.). London: Hurst.

Anderson, K. (2018). Humanitarian Inviolability in Crisis: The Meaning of Impartiality and Neutrality for U.N. And Ngo Agencies Following the 2003-2004 Afghanistan and Iraq Conflicts. Retrieved from https://ssrn.com/abstract=524082

Minear, L., \& Smith, H. (2007). Humanitarian diplomacy. Tokyo: United Nations University Press.

\section{Copyright Disclaimer}

Copyright for this article is retained by the author(s), with first publication rights granted to the journal.

This is an open-access article distributed under the terms and conditions of the Creative Commons Attribution license (http://creativecommons.org/licenses/by/4.0/). 